\title{
Czechoslovakia strengthens science and technology
}

LASI year, Czcchoslovakia embarked on what was described as a "complex experiment in effectiveness and quality control"-which to Western observers secmed virtually a reform of the economy save that "economic reform". to the Czechs, is an expression tainted by memories of the Dubcek regime. Last month. the meeting of the (zechoslowak Federal Assembly carried the tendency further, by virtually rejecting the figures for the next Five Year Plan - -an event unprecedented in the history of the Czechoslovak Socialist Republic.

One change associated with the "complex experiment" was the reorganisation of the pay structure for scientific and tutorial staff at universities and other higher educational institutions. Addressing the Federal Assembly last month, Prime Minister l.ubomir Strougal observed: "The salary conditions of scientific and tutorial staff of the higher educational institutes [polytechnics and universities] were regulated with effect from 1 October. 1978. We believe this. however. to be only one partial step designed to raise the interest of specialists from scientific and research institutes [which do no teaching] and from practical places of work in taking up jobs in higher educational institutes."

Although details of the new "con- ditions" are not forthcoming, the trend accords with the general tenor of Strougal's speech and the other discussions in the General Assembly.

Czechoslovakia is the most reluctant member of the comecon bloc when it comes to the purchase of foreign technology or know-how; the economic proposals outlined last month envisaged a cut-back in imports of all kinds and a greater dependence on home resources.

Officially, this change was linked to the word energy situation. Since September. 1976, when the Soviet Union suddenly increased oil prices to Comeccn. Czechoslovakia has had a growing energy problem, which has been only partially met by the staggering of working hours. Strougal's speech contained six major proposals in the energy sector: expansion of capital expenditure on home fuel and energy production, a crash programme for the development of the North Bohemian lignite reserves. intensified research into the "complex of problems" ranging from investment to social welfare) associated with plan fulfilment in the deep mines of the Ostrava-Karvina area, an extension of nuclear gencrating capacity to 3.500 MW by 1978 and $8,000-10,000 \mathrm{MW}$ by 1990. further participation in transit programmes, allowing "various forms of energy" (eg, natural gas) from the Soviet Union to cross Czechoslovak territory and the implementation of fuel-saving programmes, aimed at saving some $20 \mathrm{~m}$ tonnes of fuel per year.

Regarding this energy programme. Strougal noted that the total savings envisaged would not be possible immediately, but that substantial progress "must be registcred in the remaining ycars of the current Five Year Plan, and especially in the next Five Year Plan". In his main speech the Prime Minister did not, of course, make any reference to the accidents which the Charter 77 movement allege took place at the Jaslovske Bohunice nuclear power station in January 1976 and February 1977.

It was left to a relatively minor member of the Assembly, Deputy' Dana Kancirova. to raise this inauspicious subject. Even she approached it in a roundabout manner, asking for an explanation concerning the current Austrian press campaign about the safety of nuclear power stations. Mr Strougal answercd. somewhat airily, that "our present and planned nuclear power stations are of the Voronezh type, different from the one at Zwentendor" 'The alleged fatal accidents at Jaslovske Bohunice. he added, were simply "a fabrication of bcurgeois propaganda". Vera Rich

\section{Islamic scientists prepare for UNCSTD}

\section{Ziauddin Sardar discusses the Muslim countries' views on development and the role of Islamic science}

THE Islamic Secretariat is to submit a position paper. representing the views of its 42 member countries to the United Nations Conference on Science and Technology for Development in Vicnna next August. The paper is the final outcome of a conference heid in Jeddah on 17-21 March and has at least two novel features: it is the first effort by the Islamic bloc to represent an Islamic viewpoint on science and technology at the level of the United Nations and it forces the Muslim countries to recognise that there can be no effective development without the evolution of indigenous science and technology:

Implicit in the first point is the assumption that there is an Islamic alternative to the conventional practice of science and technology. That the Jeddah conference could not go heyond vague statements of this alternative is not surprising: the Muslim civilisation has been dormant for over three hundred years and current ideas on Islamic science and Muslim technology emerged only at the turn of the decade. Clearly there is a great deal of work and much analysis to be done before anything concrete cmerges. The Islamic Secretariat paper provides recognition to these ideas and should give them an international hearing.

The second feature is important because. when the paper is endorsed by the Tenth Islamic Conference of Foreign Ministers in May, the Muslim countries will become actively committed to the establishment of ministries and/or other high-powered bodies for science and technology. This may not appear to be much of an achievement from the perspective of the industrialised countries, but only half a dozen of the 45-odd Muslim countries currently have ministries and other national bodies devoted entircly to science and technology.

Billed as "The First Muslim Science conference". the Jeddah mecting was convened by the Ninth Islamic confer-
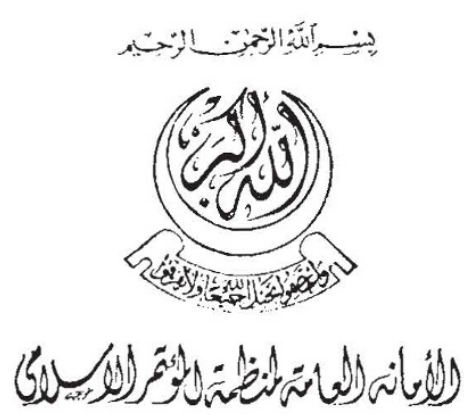

Emblem of the Islamic secretariat

ence of Foreign Ministers, held in April 1978. The science conference itself was a shambles. Of the thirty-odd delegates who attended only seven could be classified as scientists: the rest were all career diplomats. Although it was never openly admitted, the dominant presence of the civil servants was clearly embarrassing to the scientists who were cager to produce a powerful position paper.

What is surprising is that the sciontists managed to carry the confercnce and produce a coherent and 
reasonably well argued paper. They see UNCSTD as the first step towards the establishment of a "new world order in science and technology". Dr A Abou El-Azm, who is tipped to be the first director of IFSTD, argued for a strong action-orientated paper that does not undermine the position of the Group of 77, and Dr Ali Mohammed Kamel, a consultant to the Arab League Educational, Cultural and Scientific Organisation (ALESCO) repeatedly asked for the paper to be connected with the call for a New International Economic Order.

Dr Waqar Husaini of the Civil Engineering Department, King Abdul Aziz University, was more concerned with emphasising the issues of ethics and morality of science. "Islamic development", he argued, "is concerned with individual and self-purification and with growth that does not transcend the ethical boundries of Islam. Science and technology do not have an independent existence under Islam. To the contrary, they are subject to the value principles of Islam"--a point that was also echoed by other delegates.

Dr Yalgin Tuncer of Middle East Technical University was not very optimistic about the outcome of UNCSTD and argued that the Islamic position paper should be addressed not so much to UNCSTD but more to Muslim countries. "We should have a crystallised model of Islamic science and technology and its role in development; and we should offer this model to Muslim countries for study and application", he said. It was finally agreed that the paper will address the UNCSTD meeting, the Muslim countries and IFSTD.

The paper airs many concerns common to the developing countries; the lack of awareness in the Muslim world of the key role of science and technology in development; the quality and quantity of available manpower; the brain drain; the exploitative practices of western governments and multinational corporations in the field of technology transfer; lack of information on the choice of available technology; and the adverse repercussion of the politics of aid.

Unfortunately, examination of these issues is devoid of self-analysis. Placing the shortcomings squarely at the door of the West has become a common practice with the developing countries. The Islamic Secretariat's paper could have provided a lead by closely examining the attitudes and outlooks that prevent science and technology from taking indigenous roots in the Muslim world.

Also absent from the paper is an awareness of the ideological stance of science. The Islamic Secretariat's paper asserts that "there are no ideological obstacles to a vigorous introduction of science and technology in Muslim coun- tries". This is not altogether true. Traditional Muslim intellectuals do not see science as an entirely value-free, apolitical activity; and their experiences have confirmed their views. The Islamic Secretariat's paper largely overlooks this viewpoint and asserts that problems only exist in the realm of transfer and adoption of technology.

However, a slight awareness that the situation may be more complex appears in the statement that "it is not always possible to separate science and technology from the philosophical background and social forms attached to them in their country of origin". Hence, it is argued, it is necessary to develop an Islamic philosophy of science. The paper states: "Science is a common human heritage and almost all nations have contributed to it ane time or another. Muslims, in particular,

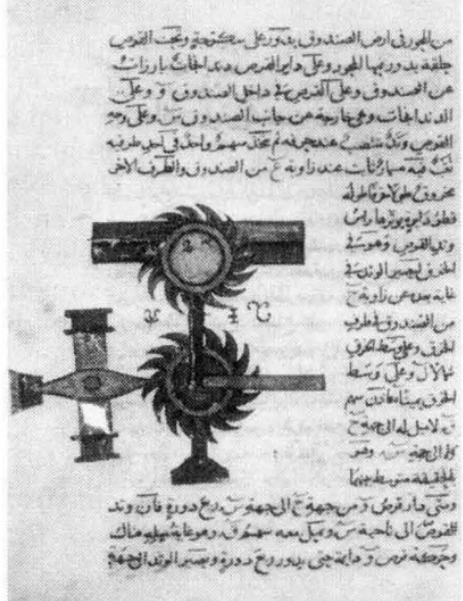

have made some of the most decisive contributions. . . Hence it is an absolute fallacy to see science and technology as the sole product of Western culture". But there is an inductive leap that leads the paper to conclude that it is therefore possible to fit conventional practices of science and technology into Islamic social and ideological systems. The first step towards this goal is said to be the popularisation of education, training and the professional practice of science and technology. Here there is an acute shortage of good technical translators and qualified scientists who can teach in indigenous languages. Those who can teach do so only in a foreign language, for they themselves were either trained abroad, or by foreigners locally. Scientists and technologists trained abroad, particularly, present a tremendous resistance against popularisation.

The paper rightly blames the frustration of local scientists on the en masse transfer and purchase of western technology. This is why the Muslim countries "have not developed locally effective institutional mechanisms and expertise to ensure performance of various functions for assessment and selection of appropriate technologies and for successful implementation and adoption of these technologies in the productive sectors". But in turn. this technological weakness is the main reason for the failure of technology transfer and for the technological dependence of the Muslim world. The prescription for shaking off this dependence asks Muslim governments to individually and collectively: formulate their policies for choice, transfer, and development of technology; build up an infrastructure for creating and using technology; and develop competent manpower.

Although it is not specifically stated. the paper assumes that at present Muslim governments do not have science and technology policies worthy of the name. A comprehensive science and technology policy is seen as a "fundamental pre-requisite for selfreliance and self-development". Further, this policy "should be integrated with the Islamic socio-economic objectives and policy and be consistent with its development priorities

The best way to turn the brain drain into the brain gain, says the paper, is to introduce and strengthen the internal "pull-factors". Such "pull-factors" could include "an Islamic sociopolitical environment, facilities for intellectual growth and professional satisfaction, logistic support at home and place of work that enables the scientists and technologists to be efficient and productive, proper salaries and privileges, merit-based promotion and recognition through a system of rewards, in-service training, continuing professional advancement, visits to advanced countries ,etc.".

This oft-preached solution has one unusual recommendation: the developed countries should be persuaded to adopt legal measures against immigration and employment of skilled Muslims from developing countries without their governments' consent.

Science and technology resources in the Muslim world are scarce. The paper's plea to the Muslim countries to share and pool their resources, therefore, makes a great deal of sense. Many Muslim countries face similar development problems. Obstacles to development in these areas could be eliminated by effective cooperation and joint action programmes. IFSTD, the paper states, will be a catalyst in this process of cooperation and coordination.

Despite its many shortcomings the importance of the Islamic Secretariat's paper for the Muslim world cannot be underestimated. Even if only half of its recommendations are actually followed up by the Muslim countries, it could change the status of science and technology in the Muslim world. And that would be no small achievement. 